\title{
Continuous infusion of simoctocog alfa in haemophilia A patients undergoing surgeries
}

Holme PA ${ }^{1,2}$ and Tjønnfjord GE ${ }^{1,2}$

${ }^{1}$ Department of Haematology, Oslo University Hospital, and ${ }^{2}$ Institute of Clinical Medicine, University of Oslo, Oslo, Norway

\author{
Address for correspondence: \\ Pål Andre Holme, MD, PhD \\ Department of Haematology, Oslo University Hospital, P.O.Box 4950, \\ Nydalen NO-0424, Oslo, Norway \\ Tel: +4723070000 \\ Fax: +4723070470
}

Email: pholme@ous-hf.no

Running title: Continuous infusion with simoctocog alfa

Keywords (6): continuous infusion, surgery, simoctocog alfa, haemophilia, bleeding, inhibitor

Words: 2488 


\begin{abstract}
Introduction:

There are two major principles for coagulation factor replacement in the clinical management of surgical procedures in patients with haemophilia, repetitive bolus injections every $6-12$ hours or administration of coagulation factor concentrates by continuous infusion.
\end{abstract}

Aim:

The aim was to investigate the efficacy of simoctocog alfa (human-cl rhFVIII) delivered by continuous infusion for bleeding prophylaxis during surgery in patients with haemophilia A.

Methods:

We investigated the use of continuous infusion with simoctocog alfa in haemophilia A patients undergoing major surgical procedures at Oslo University Hospital from Sept 2015 to March 2018. The objectives were haemostatic outcome, in vivo recovery, stability over time at room temperature (three days), and inhibitor development.

Results:

Simoctocog alfa demonstrated treatment success in terms of haemostatic efficacy in $100 \%$ of major surgeries used as $\mathrm{Cl}$ : $87 \%(n=21)$ excellent; $13 \%$ $(n=3)$ good. No erythrocyte transfusions were required in any patient, no adverse events occurred and no inhibitors developed. The product was stable 
for three days at room temperature without loss of activity. Mean in vivo recovery was $1.8(0.3)(\mathrm{IU} / \mathrm{mL} / \mathrm{IU} / \mathrm{kg})$.

Conclusion:

Continuous infusion with simoctocog alfa was found to achieve good/excellent haemostatic efficacy in all procedures. No adverse events occurred and no inhibitors developed. 


\section{Introduction}

Two major principles for coagulation factor replacement have been adopted in the clinical management of surgical procedures in patients with bleeding disorders such as haemophilia, either repetitive bolus injections (BI) every 612 hours or continuous infusion $(\mathrm{Cl})$ using a pump delivery system.

Cl was first introduced in the 1950s by Brinkhous at the Haemophilia Centre at Chapel Hill $\left[{ }^{1}\right]$. It has been used by some haemophilia treaters for decades. It is favoured by many as it provides a safe and constant level of the deficient clotting factor by balancing input with clearance thereby reducing or eliminating the risk of early or late bleeding and dangerous peaks that may lead to a thrombotic event. $\mathrm{Cl}$ may also be cost effective as it avoids the troughs and peaks associated with $\mathrm{BI}\left[{ }^{2}\right]$.

In contrast BI need to be administered every 6-12 hours and there is a certain amount of product wastage as in order to provide adequate haemostasis the trough level needs to be above a certain level. This leads to increased costs compared to $\left.\mathrm{Cl}^{3}\right]$.

Indications for $\mathrm{Cl}$ are maintenance of an efficient haemostatic coagulation factor level for a prolonged period ( $>3$ days) in association with major bleeds and major and minor surgical procedures. However, there are some concerns with the use of $\mathrm{Cl}$ of coagulation factor concentrates. Bacterial growth in the infusion bag with the risk of infectionand/or degradation of the coagulation factor concentrate during storage at room temperature are of particular importance. Phlebitis at the infusion site has regularly been reported using continuous infusion, but this can be easily avoided by adding small amounts 
of heparin to the infusion bag $(5 \mathrm{U} / \mathrm{ml})$. Previously a quite frequently reported complication was related to loss of battery power or other failures of the delivery pump system however, this is very seldom reported nowadays due to new generation of infusion pumps. Finally, suspicion has been raised that $\mathrm{Cl}$ may be associated with development of inhibitors, especially in non-severe haemophilia (although medical evidence in standard terms is lacking).

In a study comparing bolus injections (18 procedures) with continuous infusion (25 procedures) in 43 major surgical procedures performed in 40 severe haemophilia A patients Batorova and Martinowitz found improved safety of $\mathrm{Cl}$ over $\mathrm{BI}$. Higher trough levels were found in the $\mathrm{Cl}$ group $(0.44 \pm$ 0.06 vs. $0.31 \pm 0.09 \mathrm{IU} / \mathrm{mL}, p<0.01$ ) with a lower incidence of dangerous drops below $0.3 \mathrm{IU} / \mathrm{mL}$ ( $8 \%$ vs. $44 \%$ of patients, respectively; $p<0.01$ ) and a lower requirement for blood transfusions $(12 \%$ vs. $39 \%, p<0.01)$. Three of 18 patients in the $\mathrm{BI}$ group (17\%) developed major bleeding complications compared to none in the $\mathrm{Cl}$ group. Factor VIII dosage was lower by $36 \%$ in the $\mathrm{Cl}$ group $(467 \pm 104$ vs. $733 \pm 126 \mathrm{IU} / \mathrm{kg} ; \mathrm{p}<0.01)\left[^{4}\right]$.

In a cross-sectional study of the current practices in Europe regarding continuous infusion and the inhibitor incidence following this mode of treatment, Batorova et al studied 22 comprehensive care centres, where $\mathrm{Cl}$ techniques, treatment protocols, efficacy, safety and complications including inhibitor development was covered $\left.{ }^{5}\right]$. Thirteen centres used $\mathrm{Cl}$ in 1079 surgical procedures or for major bleeds in 742 patients. Nine centres which did not use $\mathrm{Cl}$ reported the following reasons for not adopting this mode of administration as 1 fear of inhibitor, 2, absence of cost benefit for $\mathrm{Cl}, \mathrm{Cl}$ more complex in comparison to $\mathrm{BI}$. Batorova et al found $\mathrm{Cl}$ to be very effective with 
a low incidence of complications: median incidence of postoperative bleeding was $1.8 \%$, six centres reported phlebitis in $2-11 \%$ of $\mathrm{Cl}$ treatments. Only nine $(1.2 \%)$ of 742 patients developed inhibitors. The incidence of inhibitors was higher in children $3 / 111(2.7 \%)$ than in adults $6 / 631(0.95 \%)$. Patients with moderate/mild disease had a higher inhibitor incidence $6 / 83-7.2 \%$ whereas patients with severe haemophilia had an incidence of $3 / 659-0.45 \%$. The three patients with severe haemophilia had a major gene defect. In five of the six patients with mild haemophilia the high risk missense mutation Arg593 Cys was present. Two of the three severe haemophilia and all mild haemophilia patients had a low number of previous exposure days to FVIII (< 50 days) prior to intensive treatment with $\mathrm{Cl}$. No local or systemic infection and/or subcutaneous infusion were reported.

Simoctocog alfa is a $4^{\text {th }}$ generation recombinant FVIII produced in a human cell line without chemical modification or fusion with any other protein, and simoctocog alfa is expressing human-specific post-translational modifications with the aim of reducing immunogenicity $\left[{ }^{6}, 7\right]$.

Clinical studies show that simoctocog alfa is highly effective in the treatment and prevention of bleeding episodes in previously treated adults and children, including those undergoing surgery $\left[{ }^{8},{ }^{10},{ }^{10}\right]$.

A recent analysis with pooled data from seven clinical studies examined the safety and efficacy of simoctocog alfa in surgical prophylaxis. The analysis comprised data from 36 patients (both adults and children) with severe haemophilia A, who underwent 60 surgical procedures (28 major and 32 minor) and were administered simoctocog alfa as BI for bleeding prophylaxis. 
Efficacy was evaluated in 52 procedures and was rated as excellent or good in all but one surgery. There was no serious treatment-related adverse events and none of the patients developed inhibitors to FVIII [ $\left.{ }^{11}\right]$.

Our aim was to investigate the use of simoctocog alfa delivered by $\mathrm{Cl}$ for major surgery in haemophilia A patients.

\section{Materials and Methods}

We investigated the use of $\mathrm{Cl}$ of simoctocog alfa in haemophilia A patients undergoing major surgical procedures at Oslo University Hospital from Sept 2015 to March 2018. The objectives were haemostatic outcome, in vivo recovery, stability over time at room temperature (3 days) and inhibitor development. Intraoperative haemostatic outcome was classified in terms of excellent (intraoperative blood loss $\leq$ average expected blood loss for the type of procedure performed in a patient with normal haemostasis and of the same sex, age, and stature), good (intraoperative blood loss $>$ average expected blood loss but $\leq$ maximal expected blood loss for the type of procedure in a patient with normal haemostasis) or none (haemostasis was uncontrolled necessitating a change in clotting factor replacement regimen) and for postoperative efficacy was classified as excellent (no postoperative bleeding or oozing that was not due to complications of surgery), good (no postoperative bleeding or oozing that was not due to complications of surgery) or none (extensive uncontrolled postoperative bleeding and oozing. Control of postoperative bleeding required use of an alternate FVIII concentrate). 
Target levels of FVIII for major surgery were at day of surgery and postoperatively days $1-3: 0.7 \mathrm{IU} / \mathrm{mL}$, day $4-6: 0.5 \mathrm{IU} / \mathrm{mL}$ and days $7-10: 0.3$ $\mathrm{IU} / \mathrm{mL}$. The day before surgery a test dose of $1000 \mathrm{IU}$ was administered to calculate the in vivo recovery and initial bolus dose. The bolus dose was then followed by continuous infusion of simoctocog alfa at a concentration of 200 IU/mL administered by a CAD mini-pump. Unfractionated heparin was added to the concentrate $(5 \mathrm{U} / \mathrm{mL})$ to avoid phlebitis. Factor VIII measurements were performed postoperatively and daily to adjust the infusion rate. The maintenance dose of $\mathrm{Cl}$ was adjusted according to clearance recalculated daily according to actual control of FVIII levels using the formula: Clearance $(\mathrm{mL} / \mathrm{kg} / \mathrm{h})=$ infusion rate $(\mathrm{IU} / \mathrm{kg} / \mathrm{h}) /$ measured factor level $(\mathrm{IU} / \mathrm{mL})\left[{ }^{12}\right]$. With regard to pharmacokinetic data, both a one-stage clotting assay (OSA) (APTT reagent Synthasil in combination with calibration plasma and FVIII deficient plasma from Instrument Laboratory (IL; Bedford, MA, USA)) and a chromogenic FVIII activity assay (Coatest SP) were assessed on a ACL TOP instrument to measure factor levels. Testing for inhibitors to FVIII was performed using the Nijmegen-Bethesda assay.

Concomitant treatment with tranexamic acid $25 \mathrm{mg} / \mathrm{kg}$ was given four times daily. No pharmacological thromboprophylaxis was used.

\section{Results}

A total of 24 major surgical procedures were performed in 17 patients. Twenty-two of these were orthopaedic surgeries, four ankle arthrodeses, six knee arthroplasties and three hip arthroplasties. Patients' ages ranged from 
28 to 71 years. There were 11 patients with severe haemophilia A, five with moderate haemophilia A and one patient with mild haemophilia A. Mean in vivo recovery was $1.8(0.3)(\mathrm{IU} / \mathrm{mL} / \mathrm{IU} / \mathrm{kg})$. The initial loading dose (bolus) was a mean of $36.3 \mathrm{lU} / \mathrm{kg}(\min 11-\max 50.8 \mathrm{lU} / \mathrm{kg})$. Continuous infusion dose on days $1-3$ was a mean of $54.9 \mathrm{IU} / \mathrm{kg} / \mathrm{d}(\min 25-\max 91 \mathrm{lU} / \mathrm{kg})$, and on days 4-6 was a mean of $35.7 \mathrm{lU} / \mathrm{kg} / \mathrm{d}(\min 9-\max 54 \mathrm{lU} / \mathrm{kg})$. The mean coagulation factor consumption for major surgery was 29,750 IU during the first nine days. The amounts of concentrate administered and the type of surgery are shown in Table 1.

Simoctocog alfa demonstrated treatment success in terms of haemostatic efficacy in $100 \%$ of major surgeries used as $\mathrm{Cl}$ : $87 \%(n=20)$ excellent; $13 \%$ $(n=3)$ good. No erythrocyte transfusion was required in any patient. Figure 1 shows the effect of continuous infusion in a patient with severe haemophilia $A$ undergoing ankle arthrodesis. As shown FVIII levels were well maintained over the course of eight days post-surgery.

\section{Safety}

No adverse events related to simoctocog alfa were observed, and no patients developed an inhibitor to the factor concentrate.

\section{Stability}


Simoctocog alfa was dissolved to a concentration of $200 \mathrm{IU} / \mathrm{mL}$ and was found to be stable for 3 days both when measured by a one-stage clotting assay based method and chromogenic assay (Table 2).

\section{Discussion}

Our study show that the effects of $\mathrm{Cl}$ with simoctocog alfa in 17 patients undergoing 24 surgeries procedures were excellent or good in all cases. The results reflect the results obtained in the GENA studies in which the efficacy of BI was rated as excellent or good in all but one procedure [11]. In our study no patients developed an inhibitor to simoctocog alfa. The use of $\mathrm{Cl}$ has raised concerns about the association of $\mathrm{Cl}$ with an increased risk of development of inhibitors to FVIII. There have been conflicting results in the literature. A number of inhibitor cases have been described following $\mathrm{Cl}$ with the majority being patients with moderate or mild haemophilia who were treated intensively for surgery and major bleeds $\left[{ }^{13},{ }^{14},{ }^{15}\right]$. Patients with mild or moderate haemophilia given $\mathrm{Cl}$ often have low exposure rates to coagulation factor concentrates. In our study the majority of patients had severe haemophilia $A$, and they had a higher number of exposure days than those with mild or moderate disease. This is borne out in a large retrospective survey on inhibitor development in European haemophilia centres using $\mathrm{Cl}$. A total of 742 haemophilia A patients who underwent $1079 \mathrm{CI}$ treatments were included [5]. Nine incidences of inhibitors developed mainly in patients with mild or moderate disease (incidence of $7.2 \%$ (6/83) compared to only $0.45 \%$ 
$(3 / 659)$ in patients with severe haemophilia. Three patients with severe haemophilia had a major gene defect and in five of six patients with mild haemophilia the high risk F8 gene missense mutation Arg 593-Cys was present. None of our patients had this mutation. The study by Batorova et al indicated that $\mathrm{Cl}$ does not increase the inhibitor risk in PTPs with severe haemophilia; an observation borne out by our study. This is in contrast to previous small case series suggesting that $\mathrm{Cl}$ may promote inhibitor development $[13,14,15]$.

However, $\mathrm{Cl}$ should be used with caution in patients $<20$ exposure days as studies have shown that the risk of inhibitor development is increased in patients with $<20$ exposure days $\left[{ }^{16}\right]$ and in mild/moderate haemophilia $A$ patients with high risk mutations.

$\mathrm{Cl}$ may reduce treatment cost compared to bolus injections, since unnecessary peaks of the coagulation factor level are avoided. Several studies have shown that coagulation factor concentrate consumption may be reduced by $\mathrm{Cl}$ compared to repetitive $\mathrm{BI}$. The area under the curve (AUC) is two-thirds of the use of $\mathrm{BI}$ [25]. We found that the mean coagulation factor consumption in major surgery was 29,750 IU during the first nine days. $\mathrm{Cl}$ with simoctocog alfa in our study showed an estimated $46 \%$ lower consumption of factor concentrate compared to the GENA surgical studies where repetitive BI were used. (320 IU/kg versus $591 \mathrm{lU} / \mathrm{kg}$ ) [11] which is also in accordance to what was reported by Batorova et al (36\%) [4]. In our study we adjusted the infusion rate to reach a FVIII level of $70 \%$ during days $0-3,50 \%$ for days $4-6$, and $30 \%$ for days 7 and beyond. We believe that this approach is necessary 
to reduce the need for erythrocyte transfusions and avoid the use of pharmacological thromboprophylaxis following surgical procedures.

There was no evidence of risk of infection from our study. To avoid any risk of infection during $\mathrm{Cl}$,preparation and filling of the container must be performed under sterile conditions. Bacterial growth in cultures from minipump reservoirs and infusion sets appear not to be a problem within 72 hours. Extensive studies have shown that FVIII and FIX concentrates are poor growth mediums for the majority of bacterial strains $[4,17,18]$.

Most concentrates are stable after reconstitution at room temperature. We found that simoctocog alfa was stable for three days at room temperature. Stability studies performed in the early 1990s showed that most concentrates were stable after reconstitution at room temperature for 3 days or more $\left[{ }^{17}\right]$. The newer recombinant products have shown extended stability over 24-48 hours $\left[{ }^{18}, 19,20,21,22,23\right]$. However, for safety reasons it is advisable to test the stability of each concentrate intended for use with the particular infusion set to be used.

None of our surgeries was associated with adverse events. Previously phlebitis at the infusion site was often reported, most likely due to high osmolality of undiluted coagulation factor concentrate. In a meta-ananlysis of Cl publications from 1992 to 2004 Hermans et al observed this complication in $10.5 \%\left[{ }^{24}\right]$. Currently phlebitis at the infusion site is very seldom seen after addition of small amounts of heparin $(5 \mathrm{U} / \mathrm{mL})$ in the infusion bag or parallel infusion of saline $\left[{ }^{25}, 26,27\right]$. This practice is well documented in a study in 
Europe [5] and in other series $\left[{ }^{28},{ }^{29}\right]$. We added small amounts of heparin (5 $\mathrm{U} / \mathrm{mL}$ ) to the infusion bag, and no sign of phlebitis was observed.

Pump failure leading to an unexpected and dangerous drop in coagulation factor level are very seldom reported due to increased quality of pumps used in current practice [12]. There were no incidences of pump failure in our study.

\section{Conclusion}

Continuous infusion with simoctocog alfa was found to achieve excellent haemostatic efficacy in the majority of surgeries. No adverse events occurred and no inhibitors developed.

\section{Acknowledgements}

Writing support was provided by Ros Kenn, Medical Writer, and funded by Octapharma.

PAH performed the research, designed the research study, contributed essential reagents or tools, analysed the data and wrote the paper. GET contributed in designing the research study and in the writing the paper.

\section{Declaration of interests}

The department has received grant/research support from Octapharma.

\section{References}

\footnotetext{
${ }^{1}$ Brinkhous KM. Hemophilia. Bull NY Acad Med. 1954;30:325.
} 
${ }^{2}$ Hathaway WE, Christian MJ, Clarke SL, Hsiba U. Comparion of continuous and intermittent factor VIII concentrate therapy in haemophilia A. Am J Hematol. 1984;17:85-88.

${ }^{3}$ Batorova A, Martinowitz U. Continuous infusion of coagulation factors: current opinion. Curr Opin Hematol. 2006;13(5):308-15.

${ }^{4}$ Batorova A, Martinowitz U. Intermittent injections vs. continuous infusion of factor VIII in haemophilia patients undergoing major surgery. Br J Haematol. 2000;110(3):715-720.

${ }^{5}$ Batorova A, Holme P, Gringeri A et al. Continuous infusion in haemophilia: current practice in Europe. Haemophilia. 2012; 18(5):753-9.

${ }^{6}$ Liesner RJ, Abashidze M, Aleinikova O, et al. Immunogenicity, efficacy and safety of Nuwiq ${ }^{\circledR}$ (human-cl rhFVIII) in previously untreated patients with severe haemophilia A-Interim results from the NuProtect Study. Haemophilia 2018; 24(2): 211-220.

${ }^{7}$ Peyvandi F, Mannucci PM, Garagiola I, et al. A Randomized Trial of Factor VIII and Neutralizing Antibodies in Hemophilia A. N Engl J Med 2016; 374(21): 2054-64.

${ }^{8}$ Tiede A, Oldenburg J, Lissitchkov T, et al. Prophylaxis vs. on-demand treatment with Nuwiq $\left({ }^{\circledR}\right)($ Human-cl rhFVIII) in adults with severe haemophilia A. Haemophilia 2016; 22(3): 374-80.

${ }^{9}$ Klukowska A, Szczepański T, Vdovin V, et al. Novel, human cell line-derived recombinant factor VIII (Human-cl rhFVIII, Nuwiq ${ }^{\circledR}$ ) in children with severe haemophilia A: efficacy, safety and pharmacokinetics. Haemophilia 2016; 22: 232-9.

${ }^{10}$ Lissitchkov T, Hampton K, von Depka M, et al. Novel, human cell line-derived recombinant factor VIII (Human-cl rhFVIII, Nuwiq ${ }^{\circledR}$ ) in adults with severe haemophilia A: efficacy and safety. Haemophilia 2016; 22: 225-31.

${ }^{11}$ Zozulya N, Kessler CM, Klukowska A, et al. Efficacy and safety of Nuwiq ${ }^{\circledR}$ (human-cl rhFVIII in patients with severe haemophilia $A$ undergoing surgical procedures. Haemophilia. 2018;24:70-76.

${ }^{12}$ Holme PA, Tjønnfjord GE, Batorova A. Continuous infusion of coagulation factor concentrates during intensive treatment. Haemophilia. 2018;24(1):2432.

${ }^{13}$ Sharathkumar A, Lillicrap D, Blanchette S, et al. Intensive exposure to factor FVIII is a risk factor for inhibitor development in mild haemophilia A. $J$ Thromb Haemost. 2003;1:1228-1236.

${ }^{14}$ Von Auer $\mathrm{CH}$, Oldenburg J, von Depka M, et al. Inhibitor development in patients with haemophilia A after continuous infusion of FVIII concentrates. Ann NY Acad Sci. 2005;1051:498-505.

${ }^{15}$ Eckhardt CL, Menke LA, van Ommen CH, et al. Intensive perioperative use of factor VIII and the Arg593 fi Cys mutation are risk factors for inhibitor development in mild/moderate hemophilia A. J Thromb Haemost. 2009;7:930937.

${ }^{16}$ Bidlingmaier C, Deml MM, Kurnik K. Continuous infusion of factor concentrates in children with haemophilia $A$ in comparison with bolus injections. Haemophilia. 2006;12(3):212-217.

${ }^{17}$ Schulman S, Gitel S, Martinowitz U. Stability of factor VIII concentrates after reconstitution. Am J Hematol. 1994;45:217-223. 
${ }^{18}$ Martinowitz U, Luboshitz J, Bashari D. Stability, efficacy and safety of continuous infused sucrose-formulated recombinant factor VIII (rFVIII-FS) during surgery in patients with severe haemophilia. Haemophilia. 2009;15: 676-685.

${ }^{19}$ Chamourad V, Moreau S, Attali O, Negrier C. Stability and microbiological safety of clotting factor concentrates in CADD PRIZM VIP pump: a preliminary study. J Pharm Clin. 2001;20:149-156.

${ }^{20}$ Neidhardt E, Koval R, Burke E, Wame N. In vitro evaluation of B-domain deleted recombinant factor VIII (refactor) stability during simulated continuous infusion administration. Haemophilia. 2005;11:319-325.

${ }^{21}$ Henze W, Kellermann E, Larson P, Gorina E. Stability of full-length recombinant FVIII formulated with sucrose during continuous infusion using mini-pump infusion device. J Thromb Haemost. 2005;3:1530-1550.

${ }^{22}$ Fernandez M, Yu T, Bjornson E et al. Stability of ADVATE, antihemophilic factor (recombinant) plasma albumin-free method, during simulated continuous infusion. Blood Coag Fibrinol. 2006;17:165-171.

${ }^{23}$ Bonde $\mathrm{C}$, Jensen $\mathrm{M}$. Continuous infusion of recombinant activated factor VIII: stability in infusion pump system. Blood Coag Fibrinol. 1998;9:103-105. ${ }^{24}$ Hermans C, Altisent C, Batoriva A, et al. Replacement therapy for invasive procedures in patients with haemophilia: literature review, European survey and recommendations. Haemophilia. 2009; 15: 639-658.

${ }^{25}$ Martinowitz U, Schulman S. Continuous infusion of coagulation products. Int J Pediatr Hematol/Oncol. 1994;1:471-478.

${ }^{26}$ Négrier C, Shapiro A, Berntorp E, et al. Surgical evaluation of a recombinant factor VIII prepared using a plasma/albumin-free method: efficacy and safety of Advate in previously treated patients. Thromb Haemost. 2008;100:217-223.

${ }^{27}$ Prelog T, Dolničar MB, Kitanovski L. Low-dose continuous infusion of factor VIII in patients with haemophilia A. Blood Transfus. 2016;14:474-478.

${ }^{28}$ Chevalier Y, Dargaud Y, Lienhart A. Seventy-two total knee arthoplasties performed in patients with haemophilia using continuous infusion. Vox Sang. 2013;104:135-143.

${ }^{29}$ Boban A, Lambert C, Hermans C. The use of short-term central venous catheters for optimizing continuous infusion of coagulation factor concentrate in haemophilia patients undergoing major surgical procedures. Haemophilia. 2015;21:364-368. 
Table 1: Major surgical procedures and outcome using continuous infusion of simoctocog alfa in patients with haemophilia A at Oslo University Hospital, Norway.

\begin{tabular}{|c|c|c|c|c|c|c|c|c|c|}
\hline $\begin{array}{l}\text { Proced } \\
\text { ure } n r\end{array}$ & $\begin{array}{l}\text { Severi } \\
\text { ty }\end{array}$ & $\begin{array}{l}\text { Age } \\
\text { (year } \\
\text { s) }\end{array}$ & $\begin{array}{l}\text { Procedu } \\
\text { re }\end{array}$ & $\begin{array}{l}\text { Bolu } \\
\text { s } \\
\text { (IU/k } \\
\text { g) }\end{array}$ & $\begin{array}{l}\mathrm{Cl} \text { day } \\
1-3 \\
\text { (IU/kg/ } \\
\text { d) }\end{array}$ & $\begin{array}{l}\mathrm{Cl} \text { day } \\
4-6 \\
\text { (IU/kg/ } \\
\text { d) }\end{array}$ & $\begin{array}{l}\text { Haemost } \\
\text { atic } \\
\text { outcome }\end{array}$ & $\begin{array}{l}\text { Transfusi } \\
\text { ons }\end{array}$ & $\begin{array}{l}\text { Adver } \\
\text { se } \\
\text { event } \\
\text { s }\end{array}$ \\
\hline 1 & $\begin{array}{l}\text { Sever } \\
\mathrm{e}\end{array}$ & 61 & $\begin{array}{l}\text { Osteosynthe } \\
\text { sis removal }\end{array}$ & 38.0 & 48.6 & 45.0 & Excellent & No & None \\
\hline 2 & Moderate & 63 & $\begin{array}{l}\text { Ankle } \\
\text { arthrodesis }\end{array}$ & 23.6 & 60.0 & 44.0 & Excellent & No & None \\
\hline 3 & Severe & 50 & $\begin{array}{l}\text { Wrist } \\
\text { arthrodesis }\end{array}$ & 29.0 & 57,5 & 33.0 & Excellent & No & None \\
\hline 4 & Moderate & 65 & $\begin{array}{l}\text { Ankle } \\
\text { arthrodesis }\end{array}$ & 27.5 & 51.0 & 43.0 & Excellent & No & None \\
\hline 5 & Moderate & 51 & $\begin{array}{l}\text { Knee } \\
\text { arthroplasty }\end{array}$ & 50.8 & 55.4 & 22.0 & Excellent & No & None \\
\hline 6 & Moderate & 71 & $\begin{array}{l}\text { Ankle } \\
\text { arthrodesis }\end{array}$ & 33.0 & 37.0 & 21.0 & Excellent & No & None \\
\hline 7 & Moderate & 52 & $\begin{array}{l}\text { Knee } \\
\text { arthroplasty }\end{array}$ & 50.8 & 34.0 & 16.0 & Good & No & None \\
\hline 8 & Severe & 28 & $\begin{array}{l}\text { Fasciotomy } \\
\text { due to } \\
\text { trauma }\end{array}$ & 42.9 & 91.0 & 45.0 & Ilent & No & None \\
\hline 9 & Mild & 64 & $\begin{array}{l}\text { Ankle } \\
\text { arthrodesis }\end{array}$ & 11.0 & 25.0 & 9.0 & Good & No & None \\
\hline 10 & Severe & 65 & $\begin{array}{l}\text { Spinal disc } \\
\text { herniation }\end{array}$ & 37.5 & 56.0 & 45.0 & Excellent & No & None \\
\hline 11 & Severe & 52 & $\begin{array}{l}\text { Knee } \\
\text { arthroplasty }\end{array}$ & 36.5 & 51.0 & 25.0 & Excellent & No & None \\
\hline 12 & Severe & 39 & $\begin{array}{l}\text { Hip } \\
\text { arthroplasty }\end{array}$ & 35.3 & 56.0 & 42.0 & Excellent & No & None \\
\hline 13 & Severe & 62 & $\begin{array}{l}\text { Osteosynthe } \\
\text { sis removal }\end{array}$ & 37.0 & 51.0 & 45.0 & Excellent & No & None \\
\hline
\end{tabular}




\begin{tabular}{|c|c|c|c|c|c|c|c|c|c|}
\hline 14 & Severe & 62 & $\begin{array}{l}\text { Osteosynthe } \\
\text { sis removal }\end{array}$ & 30.0 & 51.0 & 39.0 & Excellent & No & None \\
\hline 15 & Severe & 56 & $\begin{array}{l}\text { Knee } \\
\text { arthroplasty }\end{array}$ & 37.6 & 75.0 & 37.5 & Excellent & No & None \\
\hline 16 & Severe & 28 & $\begin{array}{l}\text { Knee } \\
\text { arthroplasty }\end{array}$ & 35.0 & 64.0 & 47.0 & Excellent & No & None \\
\hline 17 & Moderate & 57 & $\begin{array}{l}\text { Hip } \\
\text { arthroplasty }\end{array}$ & 32.6 & 64.0 & 35.0 & Excellent & No & None \\
\hline 18 & Severe & 63 & $\begin{array}{l}\text { Hip } \\
\text { arthroplasty }\end{array}$ & 48.0 & 60.0 & 45.0 & Good & No & None \\
\hline 19 & Moderate & 58 & $\begin{array}{l}\text { Cystoscopy } \\
\text { with biopsies }\end{array}$ & 32.6 & 57.0 & 47.0 & Excellent & No & None \\
\hline 20 & Severe & 61 & $\begin{array}{l}\text { Removal of } \\
\text { knee } \\
\text { arthroplasty }\end{array}$ & 42.8 & 59.0 & 34.0 & Excellent & No & None \\
\hline 21 & Severe & 34 & $\begin{array}{l}\text { Arthrolysis } \\
\text { of the elbow }\end{array}$ & 43.4 & 84.0 & 54.0 & Excellent & No & None \\
\hline 22 & Severe & 62 & $\begin{array}{l}\text { Knee } \\
\text { arthroplasty }\end{array}$ & 43.9 & 60.0 & 40.0 & Excellent & No & None \\
\hline 23 & Severe & 62 & $\begin{array}{l}\text { Prostate } \\
\text { biopsy }\end{array}$ & 43.9 & 28.0 & 14.0 & Excellent & No & None \\
\hline 24 & Severe & 53 & $\begin{array}{l}\text { Wrist } \\
\text { arthrodesis }\end{array}$ & 30 & 36.3 & 37.7 & Excellent & No & None \\
\hline
\end{tabular}


Bolus infusion:

Figure 1. Continuous infusion of simoctocog alfa in a patient with severe haemophilia A undergoing ankle arthrodesis.

Cl: $50 \mathrm{lU} / \mathrm{kg} / \mathrm{d}$

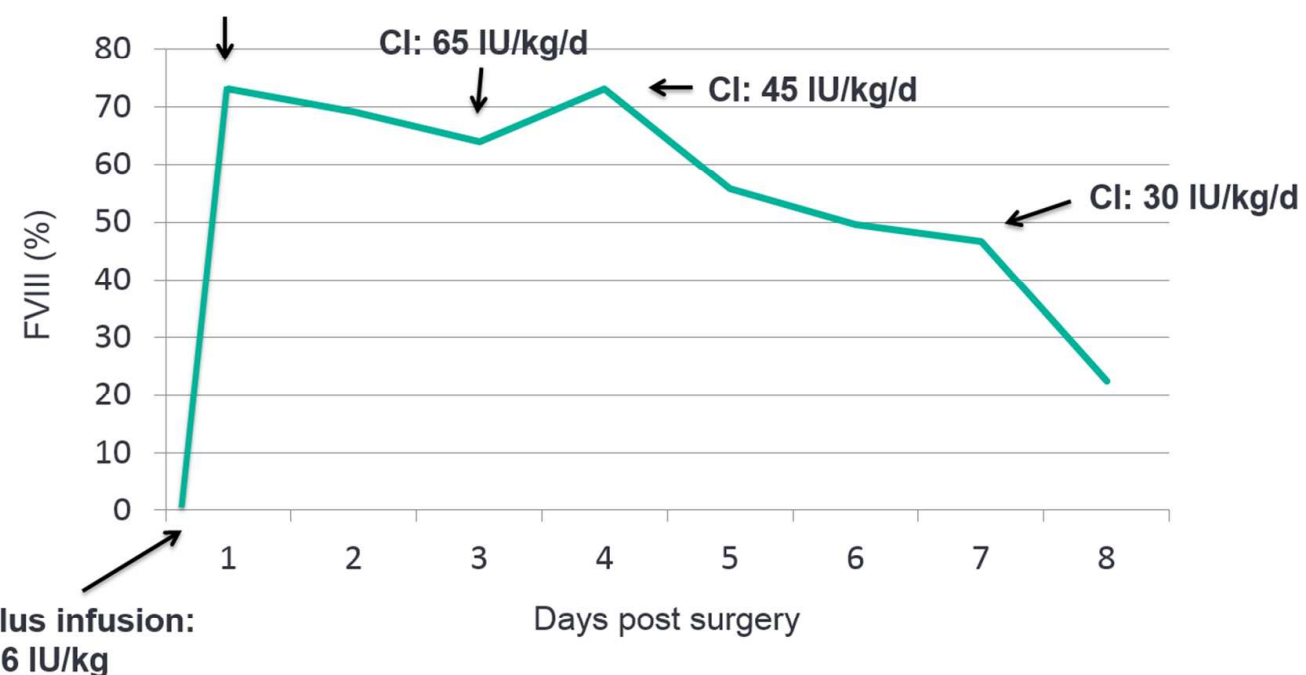

(Recovery: 2.66)

Table 2. Stability of simoctocog alfa over three days measured with a onestage assay and chromogenic assay.

\begin{tabular}{|r|r|r|}
\hline & One- stage assay & Chromogenic assay \\
\hline Day 1 & $328 \%(3.8)$ & $373 \%(12)$ \\
\hline Day 2 & $318 \%(4.12)$ & $366 \%(15.3)$ \\
\hline Day 3 & $343 \%(2.3)$ & $344 \%(7.8)$ \\
\hline
\end{tabular}

Simoctocog alfa was dissolved to a concentration of $200 \mathrm{IU} / \mathrm{mL}$ stored over a 3 days period at room temperature. FVIII activity measured with one-stage assay and chromogenic assay. (Data shown in mean (SD) ). 